\title{
複断面河道の抵抗予測と河道計画への応用
}

\section{PREDICTION OF FLOW RESISTANCE IN COMPOUND CHANNELS AND ITS APPLICATION TO DESIGN OF RIVER COURSES}

\author{
福岡捷二*・藤田光一** \\ By Shoji FUKUOKA and Koichi FUJITA
}

\begin{abstract}
Laboratory tests were performed to evaluate the interaction of the flow between a main channel and floodplains. In the tests, prismatic channels similar to actual river courses were used. The experimental results showed that the increase in Manning's roughness coefficient due to the interaction could be predicted by estimating an apparent shear stress acting on a vertical plane along a interface between a main channel and flood plain. The mixing coefficient at the interface $f$ can be almost constant and its value is around 0.17 . On the basis of the prediction method obtained, the classification diagram for the estimation of the flow resistance in the compound channel was proposed, by which discharge capacity is calculated well in accordance with characteristics of river course, compared with the existing method. Further more, it becomes known how the resistance to flow varies with the change in the cross-section by river improvement works.
\end{abstract}

Keywords : compound channel, flow resistance, flow interaction

\section{1. 序論}

わが国の河川の河道断面の多くは, 扇状地河道を除い て, 低水路と高水敷からなる複断面形状をなしており, 規模の大きい洪水が発生したときには, 複断面河道での 流れとなる．複断面河道内の流れは，単断面河道内の流 れと異なる特性を示すことから，その抵抗予測に際して は, 複断面河道内の流れの特徴を十分考慮する必要があ る. 従来, 複断面河道の抵抗予測手法として一般的に用 いられてきたのは, 高水敷と低水路の流れの境界に干渉 がなく，この干渉に伴う抵抗増加がないと仮定した断面 分割法とよばれる手法である ${ }^{1)}$. 井田は, この手法を, 水深に比べて幅の大きい任意横断面形状をもつ河道の不 等流計算に適用する方法 ${ }^{2)}$ (井田の方法とよばれる) を 開発しており, 河川砂防技術基準 $(\text { 案 })^{3)}$ では, 複断面 河道を対象とした不等流計算に際しては井田の方法を用 いることが示されている. しかし，複断面形状を有する 水路において水位が高水敷の高さをわずかに上回る際, 低水路の平均流速が水位の増大とともに減少し, 断面分

* 正会員 Ph.D., 工博 東京工業大学助教授 工学部土木 工学科 (元・建設省土木研究所河川部河川研究室長)

** 正会員 工修 総合研究開発機構研究企画部研究員 (元· 建設省土木研究所河川部河川研究室研究員)

（テ163 新宿区西新宿 2-1-1 新宿三井ビル 37 階）
割法の仮定を用いて計算された流速よりも小さくなるこ とが, 実験によっても実河道の洪水流観測によっても確 認されている ${ }^{4) ~ 6)}$. 実測值と断面分割法による計算值と のこのようなずれは水位予測の精度を低下させることか ら，その原因を解明し従来の粗度係数予測手法を改良す ることは河道計画上重要な課題である. 一方, 複断面河 道においては低水路の流れと高水敷上の流れが相互に干 渉し合い，境界付近では複雑な状況を示すことが知られ ており，低水路亡高水敷の境界付近に発生する大規模渦 や組織的な乱れの構造5),7),8) および相互干渉が疎通能力 に与える影響11),12),14) 221 などについて多くの研究がなさ れている. しかし, これらの研究の多くは, 実河道に比 較して水深幅比の著しく大きいゆがめられた河道形状, 流れを対象にした実験に基づいて行われており，基本的 な現象の解明には役立つものの, それらの結果をそのま ま実河川の抵抗予測に適用することは困難である.一方, 著者らは，比較的実河道に近い形状をもつ実験水路を用 いて複断面水路の抵抗特性を調べたが ${ }^{23)}$, 高水敷と低水 路の粗度係数が等しい条件だけを対象にしたため, 一般 的な抵抗予測手法の議論をするに至らなかった。

そこで本研究では, 実河道に近い種々の形状をもつ実 験水路において, 低水路粗度係数と高水敷粗度係数が等 しい場合亡異なる場合の 2 つの条件で, 複断面河道の粗 
度係数を測定し，断面分割法による粗度係数予測值との ずれがよ゙のような条件で顕著になるかを明らかにした。 この結果をもとに, 相互干渉の影響を考慮した粗度係数 予測手法について検討した，以上の結果から，実河川の 複断面河道における粗度係数予測手法の確立を試みた.

\section{2. 複断面河道の粗度係数予測手法についての 考察}

\section{（1）断面分割法による合成粗度係数の予測}

断面分割法では，図一1 に示すように断面を高水敷と 低水路に分け，それぞれの断面において等流条件が成立 するという仮定から，次式に示すような流量 $Q$ と水深 $H$ との関係が得られる.

$$
Q=2 \frac{A_{f \rho}}{n_{f p}}\left(\frac{A_{f p}}{S_{f p}}\right)^{2 / 3} \cdot I_{b}^{1 / 2}+\frac{A_{m c}}{n_{m c}}\left(\frac{A_{m c}}{S_{m c}}\right)^{2 / 3} \cdot I_{b}^{1 / 2} \cdots
$$

ここで $I_{b}$ は河床勾配であり, 添字の $f p, m c$ はそれぞ れ, 高水敷, 低水路の諸量に対応することを示す.なお, ここでは，説明を簡単にするため，左右対称断面を対象 にしている．断面分割法では，高水敷と低水路の分割面 (図一1 の破線) でのせん断力を無視しており, 潤辺 $S$ には分割面を含めない。このとき，合成粗度係数 $N_{c}$ は 次式により計算される.

$$
N_{c}=\frac{A_{m c}+2 A_{f p}}{Q} \cdot R_{c}^{2 / 3} \cdot I_{b}^{1 / 2}
$$

$R_{c}$ は, 合成粗度係数 $N_{c}$ を求めるための合成径深であ る. 合成径深には, 複断面河道を対象にした抵抗予測を 行う場合に種々の長所をもつ ${ }^{9}$ 井田法による径深を用い ることが一般的である. 井田法による径深は, 高水敷と 低水路の粗度係数が等しい場合に，断面分割法による合 成粗度係数が水深によって変化しないように，通常の径 深計算法 $A / S$ を修正したものであり，式（3）で表わ される2).

$$
R_{c}=\left\{\frac{A_{m c}\left(A_{m c} / S_{m c}\right)^{2 / 3}+2 A_{f p}\left(A_{f p} / S_{f p}\right)^{2 / 3}}{A_{m c}+2 A_{f p}}\right\}^{3 / 2}
$$

以上の式 $(1) \sim(3)$ によって, $N_{c}$ の計算值が求まる.

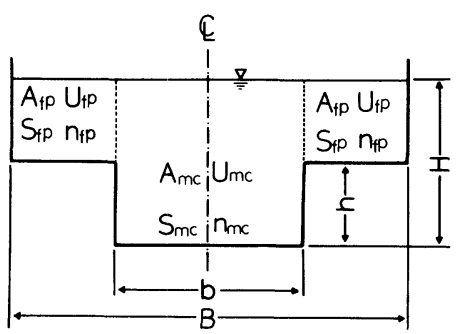

図一1 記号の説明 $(A$ : 河積, $U$ : 断面平均流速, $S:$ 潤辺, $n:$ 粗度 係数, $B:$ 全幅, $b:$ 低水路幅, $h:$ 低水路深さ, $H:$ 低水路底加 らの水深, 添字 $f p$ は高水敷を, $m c$ は低水路を表わす.)
また，ある水深に対する流量が実測により求まれば，式 ( 2 )，（3）を用いることによって， $N_{c}$ の実測值を得 ることができる. 合成粗度係数 $N_{c}$ は, 複断面河道にお ける流れの抵抗特性を簡潔に表現しており,また式 (2) からわかるように， $N_{c}$ の変化は疎通能力の変化と直接 結びついている. 以上より, 本研究では, 式 (2), (3) で定義される合成粗度係数 $N_{\mathrm{c}}$ を用いて, 複断面河道の 抵抗特性を調べることにする。

\section{（2）分割面に作用するせん断力を考慮した合成粗度 係数予測手法}

複断面河道では，流速の異なる低水路と高水敷上の流 れの間で運動量の交換が起こる. 低水路と高水敷との分 割面には，この運動量交換により見掛け上せん断力が作 用していると考えることができる．このせん断力は「見 掛けのせん断力」(Apparent Shear Stress) とよば $れ^{10), 11)}$ ，これを用いることにより，低水路と高水敷上の 流れそれぞれについて次のようなつり合い式を立てるこ とができる11),12).

$$
\begin{aligned}
& \tau_{m c} S_{m c}+\tau_{a s} \cdot 2(H-h)=\rho g A_{m c} I_{b} \\
& \tau_{f p} S_{f p}-\tau_{a s} \cdot 2(H-h)=\rho g A_{f p} I_{b} .
\end{aligned}
$$

ここで， $\tau_{m c} ， \tau_{f p}$ は，それぞれ高水敷と低水路の潤辺に おける平均のせん断力であり， $\tau_{a s}$ は，分割面に作用す る見掛けのせん断力である。断面分割法においては, $\tau_{a s}=0$ としている. 以下に, $\tau_{a s}$ を考慮した合成粗度係 数予測式を示す．まず， $\tau_{f p}, \tau_{m c}$ を次式により表わす.

$$
\begin{aligned}
\tau_{m c} & =\frac{\rho g n_{m c}^{2} u_{m c}^{2}}{R_{m c}^{1 / 3}} \\
\tau_{f p} & =\frac{\rho g n_{f p}^{2} u_{f p}^{2}}{R_{f p}^{1 / 3}}
\end{aligned}
$$

ここで, $R_{m c}=A_{m c} / S_{m c}, R_{f p}=A_{f p} / S_{f p}, u_{m c}$ : 低水路 の平均流速, $u_{f p}$ : 高水敷の平均流速, である. 式 (6), （7）は, 各分割断面の潤辺に作用するせん断力が, 単 断面河道と同様，マニングの抵抗則により分割断面内の 平均流速と関係付けられると仮定したことを意味する.

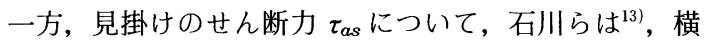
断方向に流速差のある開水路平面せん断流において $\tau_{a s}$ が流速差の 2 乗と流体の密度との積に比例するとおく と, 横断流速分布の実験值を説明し得ることを示してい る. これは, 開水路流の横断方向の流速差に伴う運動量 交換の機構が自由せん断乱流のそれと近似的に等しいと の考えに基づくものであり，同じ $\tau_{a s}$ 表示法が Evers ${ }^{14)}$, McKee ら ${ }^{15)}$ によっても提案されている.ここでは, 同 様の考えに基づき， $\tau_{a s}$ が次式により表現できると仮定 する.

$$
\tau_{a s}=\rho \cdot f \cdot\left(u_{m c}-u_{f p}\right)^{2}
$$

ここで $\rho$ は水の密度である. $f$ は低水路と高水敷との 境界での混合の激しさを表わす境界混合係数である．式 


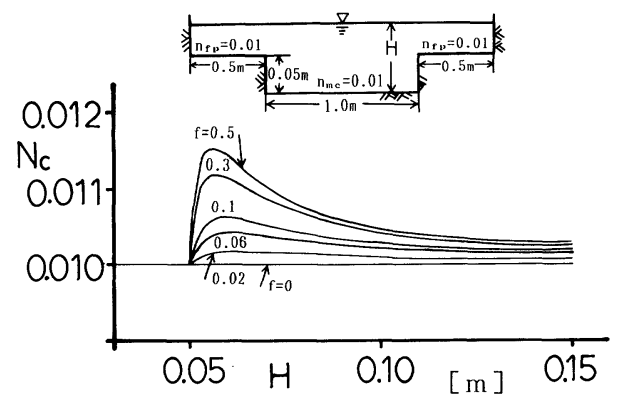

図一2 合成粗度係数 $\boldsymbol{N}_{c}$ と水深 $\boldsymbol{H}$ との関係 (計算值)

(4)〜 (8) を連立させることにより, 次式が得られる.

$$
\begin{aligned}
& \frac{\rho g n_{m c}^{2} u_{m c}^{2}}{R_{m c}^{1 / 3}}\left(\frac{b}{2}+h\right)+\rho f\left(u_{m c}-u_{f p}\right)^{2}(H-h) \\
& =\rho g H \frac{b}{2} I_{b} \\
& \frac{\rho g n_{f p}^{2} u_{f p}^{2}}{R_{f p}^{1 / 3}}\left(\frac{B-b}{2}+H-h\right)-\rho f\left(u_{m c}-u_{f p}\right)^{2}(H-h) \\
& =\rho g(H-h) \frac{(B-b)}{2} I_{b}
\end{aligned}
$$

未知数は $u_{m c}, u_{f p}$ であり, 上 2 式を連立させて解けば $u_{m c}, u_{f p}$ が得られ，これらの結果から任意の水位に対 する流量を求めることができる，流量が求まれば，式 ( 2 )，（3）より $N_{c}$ を計算することができる. 図一2に は, 低水路と高水敷の粗度係数が等しい場合の合成粗度 係数の計算例が， $f$ をパラメーターとした実線で示さ れている. $f=0$ の計算值が断面分割法による合成粗度 係数を表わす. 図より，断面分割法の $N_{c}$ は水深によら ず一定であるのに対し， $\tau_{a s}$ を考慮した $N_{c}$ は水位が高 水敷上にのったときに増加し，低水路と高水敷の流れの 相互干渉の影響が $N_{c}$ に表現されていることがわかる.

本方法を実用的なものとするには, 境界混合係数 $f$ の大きさを知らなければならない，そこで，実験によっ て $f$ 值を調べ, 本方法の妥当性を明らかにするととも に, $f$ 值に代表される混合の強度が複断面河道のどの ような因子の影響を受けるかを調べる.

\section{3. 実 験内容}

図一1に示されるような複断面河道の横断面形の特性 は, $b / B, b / h, H / h$ という 3 つのパラメーターで表わ される.これらは低水路流と高水敷上の流れとの混合形 態を支配する重要なパラメータ一と考えられる. そこで, これらのパラメーターが混合形態に与える影響を把握す ることを目的として, 数種の $b / B, b / h$ をもつ複断面 水路を対象とした実験を行った. 実験における $b / B$ 亡 $b / h$ の具体的な数值を設定する際の参考にするため, 全国主要河川から抽出した 55 地点における $b / B$ と b/ $h$ との関係を調べ, 結果を図一3に示した。図から, 日

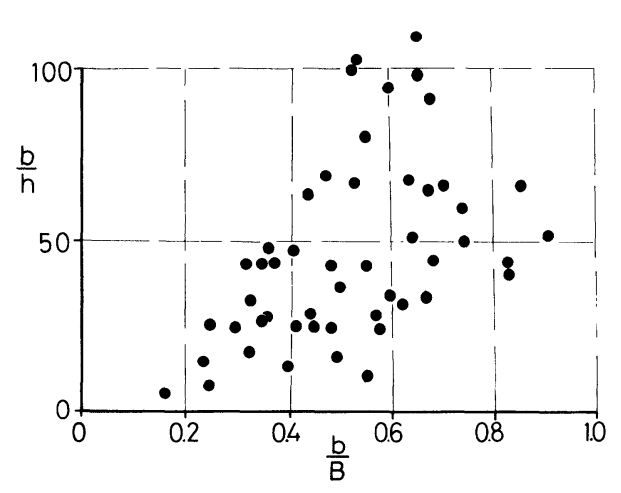

図一3 全国主要河川における $\boldsymbol{b} / \boldsymbol{h}$ と $\boldsymbol{b} / \boldsymbol{B}$ との関係

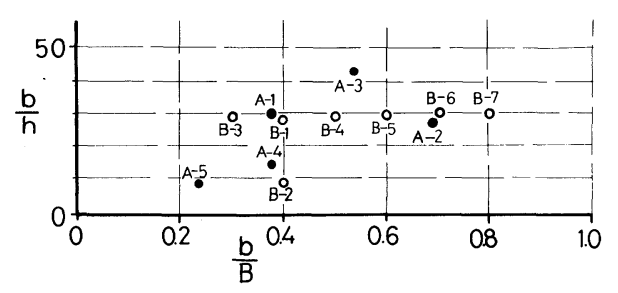

図一4実験の対象とした複断面水路形状

本の主要河川の $b / h$ は 10 から 100 の間にあり, その中 でも 20〜50に半数以上が集まっていることがわかる. ところで, 複断面河道の抵抗や見掛けのせん断力を求め るための実験は従来より数多く行われており ${ }^{11), 12), 15) ~ 22), ~}$ また, それらの実験結果に基づいて， $\tau_{a s}$ と水路形状, 水理量との間の関係を表わす式が数多く提案されてい $3^{12), 15) ~ 21)}$. しかし, これらの実験に用いられた水路は, 文献 17）を除いていずれも $b / h$ が 6 以下で水深幅比が 日本の一般的な複断面河道に比べて著しく大きい断面形 状をもっており, その結果をそのまま実河川の抵抗予測 式に用いることはできない。また, 文献 12)，16），20）, 21）以外の実験は, 低水路と高水敷の粗度係数が同じと いう条件で行われており, 高水敷粗度係数が低水路粗度 係数よりも通常大きいという実河道の条件とは異なって いる. 日本では比較的高い堤防が造られているため洪水 発生時の高水敷水深がかなり大きくなることから考えて も，高水敷水深が増大したときに低水路と高水敷との間 の流速差が小さくなる高水敷粗度係数の小さい水路だけ ではなく，高水位時にも流速差が残る高水敷粗度係数の 大きな水路での水理特性を知ることが重要である. 以上 に示した従来の実験の問題点を踏まえ, 本研究では, 図 一-3に示した日本の河川の横断面形状と実験水路の横断 面形状が極力同じ領域に入るように，図-4に示すb/ $B \sim b / h$ を実験水路諸元とした. また, 実験では, 高水 敷の粗度係数が低水路の粗度係数よりも大きい場合（以 後, シリーズ Aとよぶ）と, 低水路と高水敷の粗度係数 
表一1 実験水路の諸元

\begin{tabular}{|c|c|c|c|c|c|}
\hline 実駼一ス & \begin{tabular}{|l} 
水路長 \\
{$[\mathrm{m}]$}
\end{tabular} & 水路勾配 & $\begin{array}{c}\text { 水路帽 } \\
{[\mathrm{m}]}\end{array}$ & $\mathrm{n}_{\mathrm{mo}}$ & $n_{p p}$ \\
\hline A & 30 & 約 $1 / 1000$ & 2 & 約 0.01 & 約 0.028 \\
\hline B & 50 & 約 $1 / 1000$ & 3 & 約 0.01 & 約 0.01 \\
\hline
\end{tabular}

表一2 各実験ケースの横断面形状

\begin{tabular}{|c|c|c|c|c|c|}
\hline 实駩シリーズ & r-x番号 & $B(\mathrm{~cm})$ & $b(\mathrm{~cm})$ & $\mathrm{h}(\mathrm{cm})$ & 储 \\
\hline \multirow{5}{*}{ A } & 1 & 200 & $\begin{array}{ll}75.7 \\
\end{array}$ & 5.0 & 片恻高水数 \\
\hline & 2 & 200 & 137.8 & 5.0 & 両僛高水戟 \\
\hline & 3 & 200 & 106.8 & 5.0 & 片僛高水数 \\
\hline & 4 & 200 & 75.8 & 5.0 & 両侧高水敕 \\
\hline & 5 & 200 & 47.0 & 5.0 & 両侧高水䑤 \\
\hline \multirow{7}{*}{ B } & 1 & 300 & 120 & 4.2 & 両细高水数 \\
\hline & 2 & 300 & 120 & 12.1 & 11 \\
\hline & 3 & 300 & 90 & 3.1 & J" \\
\hline & 4 & 300 & 150 & 5.1 & "I \\
\hline & 5 & 300 & 180 & 6.0 & " \\
\hline & 6 & 300 & 210 & 6.9 & $m$ \\
\hline & 7 & 300 & 240 & 8.0 & נI \\
\hline
\end{tabular}

*両恻高水数の埸合いずれも左右対称断面

がほぼ同じ場合（以後，シリーズ B とよぶ）の 2 種類の 条件を設定した. 表一1には, 実験に用いた水路諸元を, 表一2には各実験ケースの断面形状を示す.いずれも断 面一様の直線水路である. 水路は, 粗度の小さいベニヤ 板と粗度の大きいプラスチックの多孔体を組み合わせて 造った，実験にあたっては，まず，低水路と高水敷別々 に通水して低水路と高水敷の粗度係数 $n_{m c}, n_{f p}$ を求め ておき, 次に複断面河道について低水路深さの 3 倍まで の数種の水位について流量を求めた. 同時に, 水位の縦 断分布を $3 \mathrm{~m}$ ピッチで測定した。 また, アルミ粉や染 料を投入することにより, 表面流況の可視化を行った.

実験により得られた水位の縦断変化と流量から, 各水位 測定点間ごとの粗度係数を不等流の式から逆算し, それ らを縦断方向に平均することによって合成粗度係数 $N_{c}$ を求めた。なお, 径深計算法には, 式 (3) を用いてい る.

\section{4. 実験結果と考察}

\section{（1） 高水敷粗度係数が低水路粗度係数よりも大きい} 場合（シリーズA）

図一5に, 各複断面形状についての合成粗度係数 $N_{c}$ と水深 $H$ との関係をプロットした結果を示す.なおこ の図では, $H$ が低水路深さ $h$ によって, $N_{c}$ が $n_{m c}$ によっ て無次元化されている. 図中の実線は断面分割法による 予測值である. 図から, いずれの複断面形状においても, 合成粗度係数の実測値が断面分割法による予測值よりも 大きく, また，両者の差が高水敷水深の増大とともに大 きくなっていることがわかる. 図中の破線は, 見掛けの せん断力 $\tau_{a s}$ を考慮した合成粗度係数の計算值である.

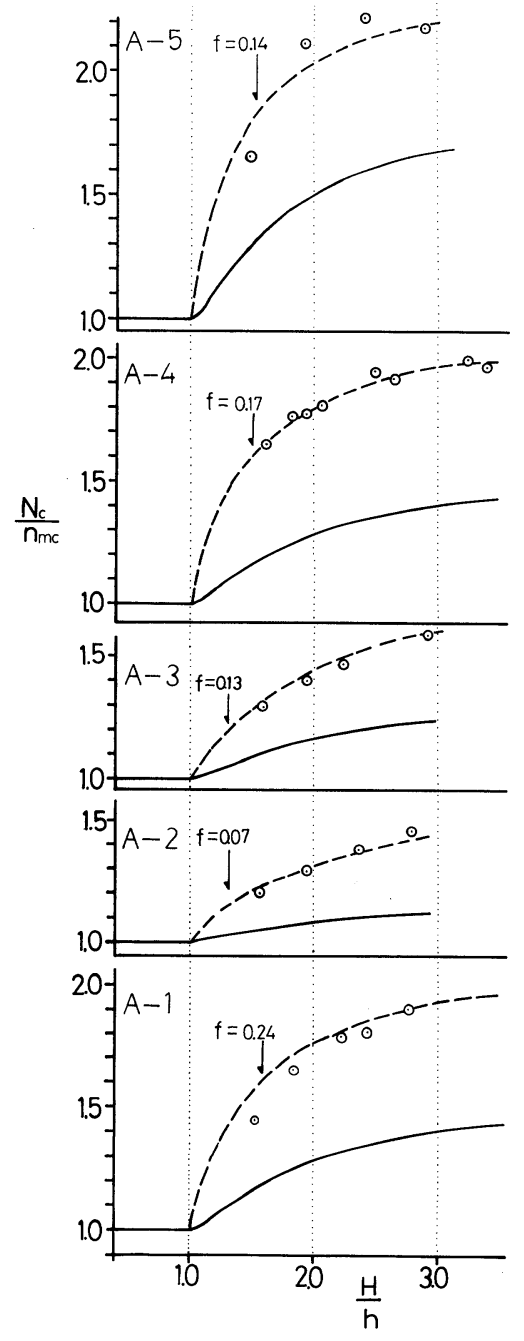

図一5 合成粗度係数 $\boldsymbol{N}_{c}$ と水深 $\mathrm{H}$ との関係 (シリーズA)

破線を計算する際に用いる境界混合係数 $f$ 值は, 実測 值之計算值が最もよく一致するように定めており，その 值が図中に示されている. 破線と実測值とを比較すれば わかるように, 適正な $f$ 值を用いて計算された合成粗 度係数值は実測值をよく再現する。

（2）高水敷と低水路の粗度係数がほぼ同じである場 合 (シリーズB)

図一6に，図一 5 と同様の方法により表示された合成 粗度係数 $N_{c}$ と水深 $H$ との関係を示す. 図中の実線は 断面分割法による予測值である.この図より以下のこと

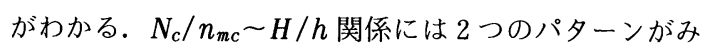
られる. 第 1 のパターンは, 低水路幅 $b$ に対する水路 全幅 $B$ の比 $b / B$ が相対的に小さい実験ケース B-1, 2, 3 でみられ，高水敷に水がのると $N_{c}$ が断面分割法によ る計算值よりも大きくなり，さらに水位が上昇すると再 


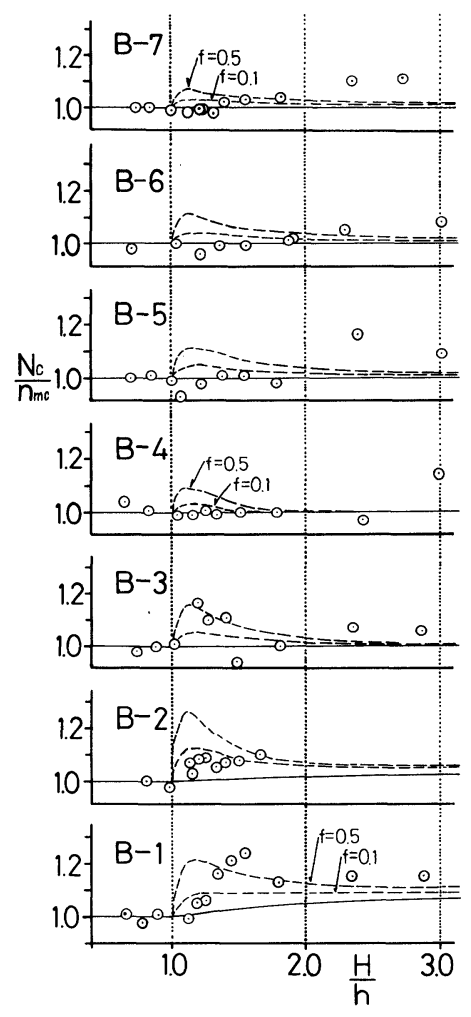

図一6 合成粗度係数 $\boldsymbol{N}_{c}$ と水深 $\boldsymbol{H}$ との関係（シリーズ B ）

び $N_{c}$ が減少して断面分割法による計算値に近づくとい うものである．この場合 $N_{c}$ は，最大で約 2 割増大する. 第 2 は， $b / B$ が大きい実験ケース B-4, 5, 6, 7 でみら れ， $N_{c}$ の増加がほとんよ゙ないパターンである. 第一の パターンで $N_{c}$ が増加するのは, 高水敷と低水路の流れ の相互干渉によるものと考元られる．図一6には， $\tau_{a s}$ を考虑した計算値が破線で示されている. 相互干渉の影 響が合成粗度係数に現われやすい領域，すなわち高水敷 水深が小さい $(1<H / h<1.5)$ 範囲において実測值と 破線を比較することにより，相互干渉の効果をよく説明 する $f$ 值の概略を知ることができる. $N_{c}$ の実験值の顕 著な増加がみられる実験ケース B-1, 2, 3 の $f$ 值は 0.1 $\sim 0.5$ 程度の值を示しているのに対して, このような増 加がみられない実験ケース B-4, 5, 6, 7 では, $f$ が大 きくても 0.1 以下の值を示している.

\section{（3）低水路と高水敷の間の混合現象}

流況観察の結果から, 複断面河道の流れには 2 種類の 特徴ある組織的な構造があることが明らかとなった。す なわち, 第 1 は, 低水路肩付近で間欠的に発生する強い ボイルである. 写真一1 はその一例を示したものである. ボイルにより底面付近の流体が表層に移動するため, 低 水路河岸付近にところどころアルミ粉のない領域が現わ
れていることがわかる. 図一7は，写真一1に対応した 断面内の流速分布を示したものである. 図中の等流速分 布は, 直径 $5 \mathrm{~mm}$ のプロペラ流速計により測定した横断 面内各点の 20 秒間の平均流速值に基づいて描いたもの である (図一8も同様).この図から，低水路河岸上の 流速がその両側に比べてかなり減少していることがわか る.これらは, 今本ら ${ }^{8)}$ が指摘している高水敷先端から の斜昇流によるものと考えられる．もう1つの特徵ある 流れの構造は, 鉛直の軸をもつ大規模な平面渦である. その一例を写真一2に示す。この渦は次のような性質を もっている. まず渦の影響範囲がほとんど高水敷内に位 置する. また渦は規則的であり，かつ長時間にわたって その形を維持する．すなわち，写真一2に示したような 高水敷上のアルミ粉のパターンがそのまま下流へ移動す る. 渦の存在が表面に散布されたアルミ粉の集散状況よ り確認できることからわかるように, 渦は水平方向の流 速変動だけではなく, 湧昇流と沈降流を伴っている. そ の構造を図一-9に示す. 大規模渦に伴って, 低水路の底 面付近の流体が高水敷へ鈶直上向きの流速成分をもちな がら輸送され, 一方, 高水敷上の流体がやや沈降しなが ら低水路へ輸送される. 前者の輸送は渦中心の下流側で, 後者は上流側で行われる. 以上より, 高水敷と低水路の 流体の混合は, 二次元的ではなく, 組織的な湧昇・沈降 流を伴う三次元的な形で行われることがわかる. 図一8 には写真一 2 に対応する横断面内の流速分布が示されて いる. 図一7にみられた低水路肩の上での低流速域はみ られない。ここで, 2 種類の組織的構造のうち, 前者を 高水敷先端からの斜昇流, 後者を大規模平面渦とよぶと, これらの発生の有無は図一10により表わされる. 図か ら, 高水敷と低水路の粗度係数が同じ場合 (シリーズ B ) には, $H / h$ の増大に伴い大規模平面渦から斜昇流へ流 れの形態が変化するのに対して, 高水敷粗度係数が低水 路に比べて大きい場合（シリーズA）には, すべての領 域で大規模平面渦の発生がみられる。これらのことは, 大規模平面渦発生の必要条件が低水路之高水敷上の流れ との顕著な流速差であることを示している，また，図一 10 から, 大規模平面渦発生の有無は $b / B$ にはほとんよ゙ 影響されないことがわかる.ただし， $b / B$ の違いによっ て大規模平面渦の形に次のような違いがみられる。すな わち, $b / B$ が大きい (0.6 程度以上) 場合には, 写真 一3に示すように, 高水敷の幅が小さいため渦が境界か らの制約を受け，ほぼ同じ大きさをもつ非常に規則的な 配列亡なる. 一方， $b / B$ が小さい (0.6 程度以下) 場 合には，渦が境界からの制約を受けなくなるため，渦の スケールがばらつき写真一2にみられるようにやや不規 則となる.

\section{（4） $\boldsymbol{f}$ 值についての考察}




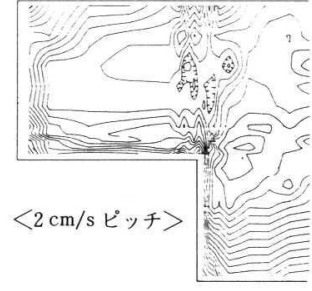

図一7 横断面内の流速分布 (ケース B-2, $H / h=2.25$ )

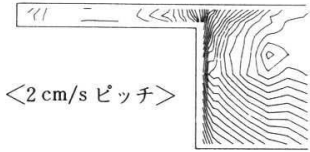

図一8 横断面内の流速分布 （ケース B-2, $H / h=1.12$ )

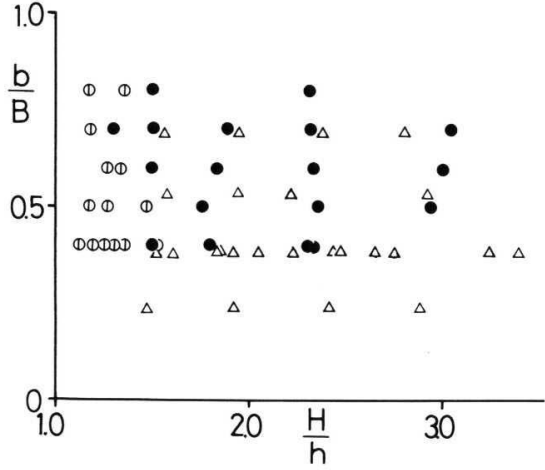

凡例

$$
\begin{aligned}
& \text { シリーズA }\left\{\begin{array}{l}
\Delta \cdots \text { 大規模平面渦 } \\
\Delta \cdots \text { 高水敷先端からの斜昇流 }
\end{array}\right. \\
& \text { シリーズ } \mathrm{B}\{\text { (1)...大規模平面渦 } \\
& \text { 高水敷先端からの斜昇流 }
\end{aligned}
$$

図一10 大規模平面渦と高水敷先端からの斜昇流の発生条件

図一11に，本実験により得られた合成粗度係数から 逆算した境界混合係数 $f$ 值と $b / B$ との関係を示す. $f$ 值は同一横断面形状の下でも水深によって多少変動する ので, 図には水深平均値とその変動幅を示した．また， 実験シリーズBでは，干渉効果による粗度係数の増加が 小さく，しかも限られた水深範囲でしか明確に現われな いので, 逆算 $f$ 值の精度が実験シリーズ $\mathrm{A} に$ に比較して 低い，そのため，図には変動範囲のみが点線で示されて いる. 図から, $b / B$ が 0.5 以上になると, $b / B$ の増大 亡ともに $f$ 值がやや減少する傾向がみられる.これは, $b / B$ が大きくなると高水敷幅が小さくなり, 低水路と 高水敷上の流れとの干渉に寄与する大規模渦が側壁の影 響を受け，渦による運動量交換量が小さくなるためと推

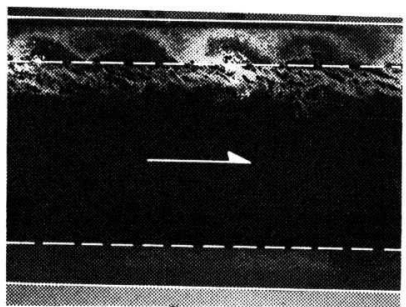

写真一3 高水敷幅が小さい場合の大規模 平面渦（ケース B-6, $H / h=1.19$ )

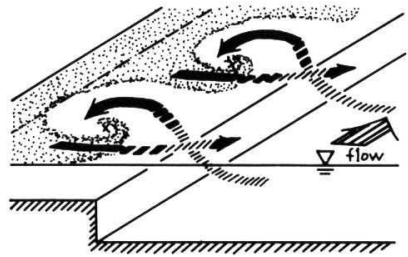

図一9 大規模平面渦に伴う流れの 三次元構造 
の流れの干渉の強度が開水路平面せん断流における混合 の強度よりも大きくなることを示している．この原因と しては，平面せん断流が二次元的な混合現象であるのに 対して複断面河道の低水路と高水敷の流れの混合が図一 9 に示したように三次元的であることが考えられる.

\section{5. 複断面河道の河道特性把握手法}

\section{（1） 河道特性把握のねらい}

洪水流の抵抗予測は, 河道計画における最も重要な検 討項目の 1 つである. 前章までの結果から, 複断面河道 の抵抗を予測するための手法が得られ，これを用いるこ とにより, 原理的には, 実河道の抵抗を実用上十分な精 度で予測することができる. しかし, 実際の河道を対象 とする場合, 低水路, 高水敷それぞれの粗度係数を精度 良く求めることが困難であり, 比較的精度良く求まる水 理量は, ある規模の洪水データの逆算により得られた合 成粗度係数だけである.したがって, 式（9)，(10)に よる合成粗度係数の予測は必ずしも実河道の合成粗度係 数予測の精度向上にはつながらない。このような状況を 考慮した場合，逆算合成粗度係数を用いることを前提に した計画洪水発生時の合成粗度係数予測の精度向上に とって重要な情報だけを, 本研究で得られた複断面河道 の抵抗特性から簡潔に抽出することが重要であると考え られる. 以下，この観点からの検討を行う.

\section{（2）複断面河道の抵抗特性を代表する特性量}

河道計画に必要な計画規模洪水に対応する合成粗度係 数を予測する最も簡便な方法は，断面内の粗度係数の分 布も干渉も考慮せず, 洪水観測デー夕から逆算された合 成粗度係数をそのまま予測値とするものである。これを 手法 1 とよび，予測值を $N_{1}$ とする. 手法 2 は，断面分 割法である。これは，合成粗度係数と水位との関係を予 測するために一般的に用いられる手法であり，予測值を $N_{2}$ とする. 第 3 は，2. で取り上げた断面分割法に高水 敷と低水路の流れの干渉による見掛けのせん断力 $\tau_{a s}$ を 考慮して合成粗度係数を予測する手法であり，これを以 後手法 3 とよび, 予測值を $N_{3}$ とする. 粗度係数逆算対 象洪水の水位は計画規模洪水の水位よりも通常小さいの で, 手法 1 では, 合成粗度係数の水深による変化が小さ いと仮定していることになる. しかし合成粗度係数は， 前章で示されたように，高水敷上の流れと低水路流れと の干渉と一潤辺内の粗度の違いが原因となって, 水位と ともに変化するのが一般的である．干渉効果が卓越する 複断面河道では, 手法 3 による予測值が実験值に最も良 く適合し, 手法 2 の予測值は, 上述の干渉効果を考慮し ていないため合成粗度係数を過小評価することになる。

一方, 合成粗度係数予測の繁雑さは, 手法 $1,2,3$ の順 に大きくなる。
$N_{3} \sim H, N_{2} \sim H$ (水深) 関係の中で, 特に次の $2 つ の$ 水理量が河道計画上重要である.

(1) $d N_{3} / d H$ : 水深の増大に伴う $N_{3}$ の増加率

(2) $N_{3}-N_{2}: N_{3}$ と $N_{2}$ との差

計画規模洪水の水深と逆算洪水の水深との差を $\Delta H$ と すると, 手法 1 には近似的に $\Delta H \cdot d N_{3} / d H$ だけ誤差が 生じる. したがって $d N_{3} / d H$ の大きさにより, 手法 1 を採用することの妥当性を判断できる. $N_{3}-N_{2}$ は, 干 渉に起因する付加的な抵抗による粗度係数増加量の大き さを表わす．この量が大きいことは，干渉による付加的 な抵抗を生じやすい河道であることを意味する，また， $N_{3}-N_{2}$ が小さいときには，手法 3 より簡便な手法 2 を 用いることが可能であると判断できる.以上の考察から， 複断面河道の水理特性を把握するための指標を $d N_{3} /$ $d H, N_{3}-N_{2}$ と考える。

\section{（3） $d N_{3} / d H, N_{3}-N_{2}$ と河道特性量との関係}

左右の高水敷の高さと粗度係数が等しい図一1に示す 単純な複断面形を対象亡する. 高水敷上の流量, 流速が 低水路内の流量, 流速に比較して小さいことから, 低水 路流との干渉による高水敷流速の増加分は合成粗度係数 の值にわずかな影響しか与えないと考えられる.そこで, 第 1 次近似として, 高水敷上の流れの力のつり合いを表 わす式（10）の代わりに，流れの干渉を表わす項を省略 した式（11）を用いる.

$$
\frac{\rho g n_{f \rho}^{2} u_{f \rho}^{2}}{R_{f p}^{1 / 3}}\left(\frac{B-b}{2}+H-h\right)=\rho g(H-h) \frac{(B-b)}{2} I_{b}
$$

式（9）と式（11）を連立させ，さらに各分割断面の径 深がそれぞれの水深に等しいとして， $N_{3}$ の第 1 近似值 $N_{3}^{\prime}$ を得る式を求め, この結果から $d N_{3}^{\prime} / d H,\left(N_{3}^{\prime}-\right.$ $\left.N_{2}\right) / N_{2}$ を計算すると, それぞれ下式で表わされる $C_{1}$, $C_{2}$ を得ることができる.

$$
\begin{aligned}
& C_{1}=\frac{d N_{3}^{\prime}}{d H}=\frac{n_{m}}{\left(x y z^{5 / 3}+A\right)^{2}} \cdot\left\{\frac{5}{3} x z^{2 / 3} z^{\prime}(A-y)\right. \\
& \left.-B\left(1+x z^{5 / 3}\right)\right\} \quad[\mathrm{m}, \mathrm{s} \text { 単位 }] \\
& C_{2}=\frac{N_{3}^{\prime}-N_{2}}{N_{2}}=\frac{(1-A)}{x y z^{5 / 3}+A} \\
& \text { ここで, } x=b_{f} / b_{m}, y=n_{m} / n_{f}, \quad z=H_{f} / H_{m} \\
& A=\frac{\theta}{(1+\theta)} \cdot y z^{2 / 3}+\frac{1}{(1+\theta)} \cdot \sqrt{1+\theta-\theta y^{2} z^{4 / 3}}, \\
& B=\frac{\theta^{\prime}}{(1+\theta)^{2}} \cdot y z^{2 / 3}+\frac{2}{3} \frac{\theta}{(1+\theta)} y z^{-1 / 3} z^{\prime} \\
& -\frac{\theta^{\prime}}{(1+\theta)^{2}} \cdot \sqrt{1+\theta-\theta y^{2} z^{4 / 3}} \\
& +\frac{1}{(1+\theta)} \cdot\left(\frac{\theta^{\prime}-\theta^{\prime} y^{2} z^{4 / 3}-\frac{4}{3} \theta y^{2} z^{1 / 3} z^{\prime}}{2 \sqrt{1+\theta-\theta y^{2} z^{4 / 3}}}\right),
\end{aligned}
$$




$$
\begin{aligned}
& \theta=\frac{S_{r} \cdot f \cdot H_{m}^{1 / 3}}{g b_{m} n_{m}^{2}}, \quad \theta^{\prime}=\frac{2 f}{g b_{m} n_{m}^{2}}\left\{\frac{4}{3} H_{m}^{1 / 3}-\frac{1}{3} h H_{m}^{-2 / 3}\right\}, \\
& z^{\prime}=\frac{h}{H_{m}^{2}}
\end{aligned}
$$

また, $b_{m}$ : 低水路幅, $b_{f}$ : 高水敷の全幅, $n_{m}$ : 低水路 粗度係数, $n_{f}$ : 高水敷の粗度係数の平均, $H_{m}$ : 低水路 水深, $H_{f}$ : 高水敷の平均水深, $S_{T}$ : 干渉によるせん断 力が作用する部分の潤辺長 (低水路の両側に高水敷があ るとき $S_{T}=2 H_{f}$, 低水路の片側にだけ高水敷がある場 合には $\left.S_{r}=H_{f}\right), h:$ 低水路深さ, $g:$ 重力加速度, で ある.このように, $d N_{3}^{\prime} / d H,\left(N_{3}^{\prime}-N_{2}\right) / N_{2}$ は河道横断 面形，低水路高水敷の粗度係数および水深によって規定 されることがわかる.

ところで図一12,13には，全国の代表的な複断面河道 について, 上記の近似，単純化を行わず式 ( 8)〜(10) に基づく数值計算より求めた $d N_{3} / d H,\left(N_{3}-N_{2}\right) / N_{2}$ と 式 (12)，(13）より求めた $C_{1}, C_{2}$ との関係を示す。こ こでデータには, 図一3に示した全国主要河川の河道横 断面形状とそこで実際に生じた洪水時の水位, 粗度係数 なよ゙の諸量を用いている， $C_{1}, C_{2}$ を導くにあたっては 近似や単純化を行っているため, それらと $d N_{3} / d H$, $\left(N_{3}-N_{2}\right) / N_{2}$ とは一致しないが，両者の間には，図に示 すように, 次に示すほぼ一意の関係があることがわかる.

$$
\begin{aligned}
& d N_{3} / d H \doteqdot C_{1} \\
& \left(N_{3}-N_{2}\right) / N_{2} \doteqdot 0.64 C_{2}
\end{aligned}
$$

以上のように, 複断面河道の抵抗特性を代表する特性量

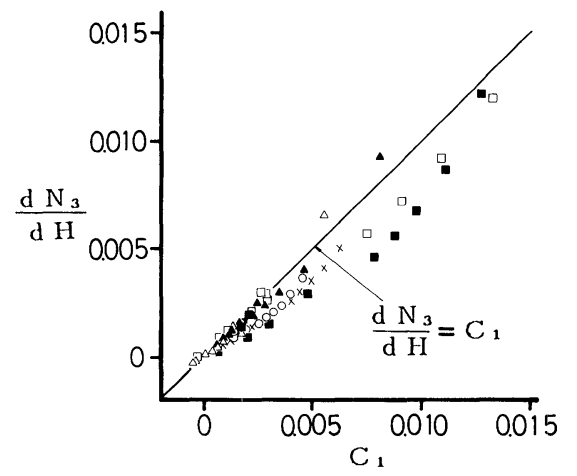

図一12 $C_{1}$ と $d N_{3} / d H$ との関係

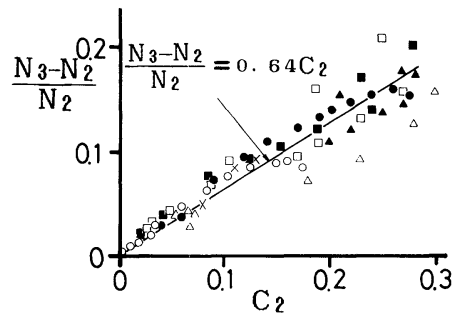

图一13 $C_{2}$ と $\left(N_{3}-N_{2}\right) / N_{2}$ との関係 $d N_{3} / d H$ と $N_{3}-N_{2}$ は，河道横断面形，高水敷・低水路 の粗度係数および水深から簡単に求められる河道特性量 $C_{1}, C_{2}$ によって表わすことができる.

\section{（4）複断面河道の抵抗予測手法の分類図}

いま，（3）で求められた $d N_{3} / d H$ と $\left(N_{3}-N_{2}\right) / N_{2}$ を 用いて, 複断面河道の適切な抵抗予測手法の選択法につ いて論じる. 図一14 は，縦軸に $\left(N_{3}-N_{2}\right) / N_{2}$ を表わす $\left[0.64 C_{2}\right]$ をとり, 横軸に $d N_{3} / d H$ を表わす $\left[C_{1}\right]$ をとる. 対象亡する河川の河道特性量から $C_{1}, C_{2}$ を計算し, そ れぞれの河川が分類図上でどの位置に属するかによって 各河川の用いるべき抵抗予測手法が決まる．すなわち， 分類図上の左方に位置すれば，水深による粗度係数の変 化が小さい $\left(d N_{3} / d H\right.$ が小) ので, 合成粗度係数予測 手法 1 の適用が可能となる. 一方, 分類図上の右方では, 手法 1 の適用は不適切となる.このとき, その位置が右 下にある場合には, $\left(N_{3}-N_{2}\right) / N_{2}$ が小さくなるので, 手 法 2 の適用が可能となるが，右上に位置する場合には， 手法 3 を用いる必要が出てくる. 図一15 は, 分類図上 の位置に応じた代表的な河道断面図を概念的に示したも のである．高水敷水深が大きい，あるいは低水路幅の広 い河道では手法 1 の適用が可能となり, 逆に, こうした 形状をもたない河道では手法 1 の適用は不適切となる. この場合低水路が深い，あるいは高水敷粗度係数が大き い場合には手法 3 の適用が必要となり，そうでない場合 では手法 2 の適用が可能となる，以上のように，複断面

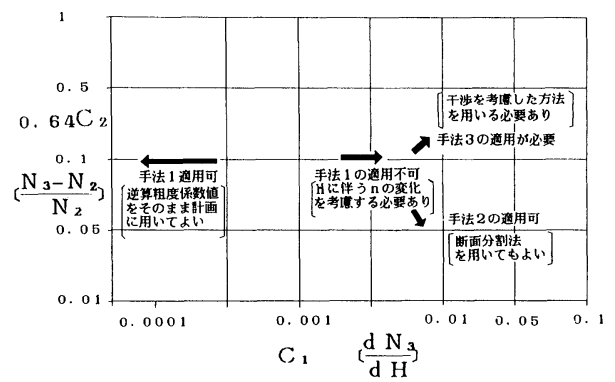

図一14 複断面河道の抵抗特性分類図と合成粗度係数予測手法 選択の考え方

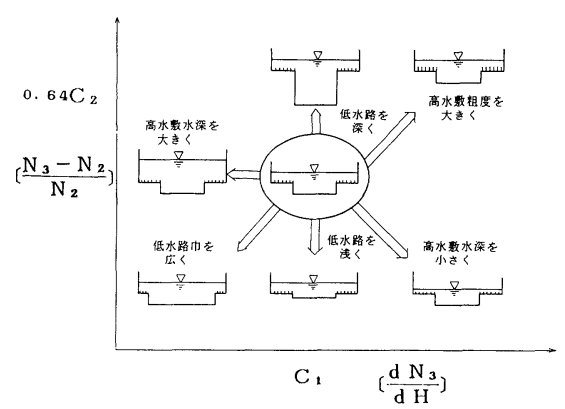

図一15 河道特性と分類図上の位置との関係（概念図） 
河道の抵抗特性分類図を用いることによって, 合成粗度 係数予測手法選定の合理的な判断を行うことができる.

\section{（5）分類図を用いた河道特性の把握}

河道計画を策定する際，当該河川の抵抗特性，全国の 河川の中での位置付け, また河道改修による河道特性量 の変化等を見積もることができる簡便な指標があれば便 利である.ここでは, 上記の河道の抵抗特性分類図を用 い, 洪水流にかかわる河道特性の把握手法を提案する.

分類図によって, 合成粗度係数の水深による変化率と干 渉効果による合成粗度係数の増加割合という洪水流に とって重要な水理特性がわかるので, これらをもとに検 討対象河道についての評価を行うことができる. 図一16 は, 計画高水位 (H.W.L) 時の現況河道の諸量を用い て上述の分類図にプロットしたものである.この図から, 各河道が全国の複断面河道の中でどのような位置付けに あるかがわかる，図一17は，図-16の各河道が現況か ら計画になる際の, $C_{1}, C_{2}$ の分類図上での変化の方向 を示したものである.この図から，C $C_{1}$ 軸については, 変化しないか負の方向に動くものがほとんどであること がわかる. このことは, 大部分の河道で, 計画高水位付 近の水深の上昇による粗度係数の増加率が不変あるいは 減少することを意味している．一方， $C_{2}$ 軸については, 正の方向に動くもの，負の方向に動くものの両方がある ことがわかる. 正の方向に動く改修は, 改修により干渉 効果が増大することを意味している. 以上のように, 複 断面河道の抵抗特性分類図を用いることにより, 各河道 がもっている疎通能力に関する特性, その全国河道の中 での位置付けを明確にすることができる. また, 改修に 伴う分類図上のプロット位置の変化から, 疎通能力の観 点からみた改修の影響評価を簡便に行うことができる.

なお, 改修に伴う河道特性変化の把握は, ここで述べ た疎通能力の観点に加えて河床変動や河岸侵食等の観点 からも行わなければならない.一例として, 図一18に 示す河床形態の形成領域区分図 ${ }^{24)}$ を用いて説明する. 図 中の矢印に例が示されているように, 改修により河道の 横断面形状や河床材料が変化すると, 河床形態の領域区 分図上でその位置が移動する. その移動が異なる河床形 態にまたがる場合には, 改修による水当たり部の新たな 発生やその位置, 程度の変化が予想され, その対策を検 討する必要が生じてくる. このように, 河床安定の観点 からも, 改修に伴う河道特性の変化をあらかじめ予測し, 先に示した疎通能力の観点からの検討と合わせて, 与え られた条件の中でより望ましい河道横断面形状を見出し ていくことが合理的な河道改修を進めるうえできわめて 重要である.

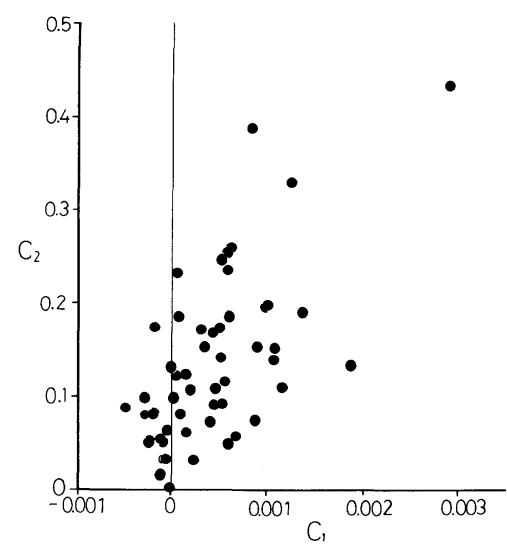

図一16 全国の代表的な複断面河道の分類図上の位置（計画高 水位時の現況河道)

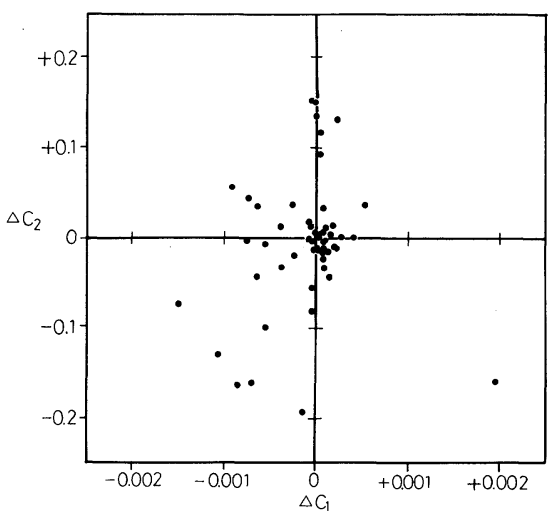

図一17 河道の状態が現況から計画に変化したときの $C_{1}, C_{2}$ の 变化の方向 $\left(\Delta C_{1}, \Delta C_{2}\right)$

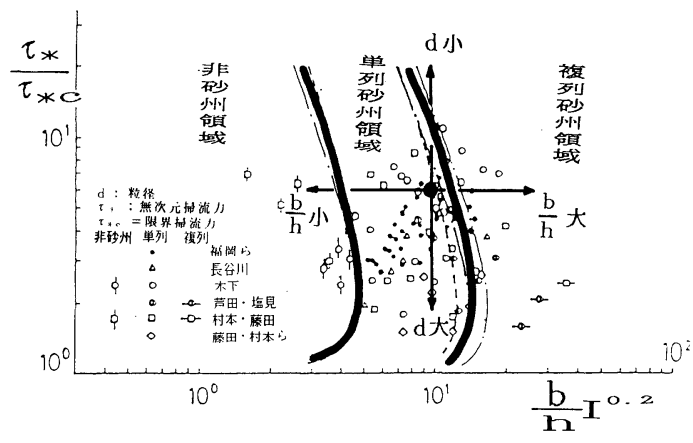

図一18 河床形態区分図

\section{6. 結 論}

実河川に近い種々の複断面形状をもつ実験水路を用い て, 複断面河道における洪水流の抵抗特性を調べ，その 結果得られた成果を用いて実際の河道計画への応用につ いて述べた. 結論を要約すると以下のようである. 
（1）高水敷と低水路の流れの干渉が原因となって両 者の境界に作用する見掛けのせん断力 $\tau_{a s}$ を考慮するこ とにより，従来一般に用いられてきた断面分割法による 合成粗度係数の予測精度を大幅に向上させることができ ることを示した。

（2）低水路幅・全幅比が 0.2 から 0.6 の範囲で, 高 水敷の粗度係数が低水路の粗度係数の 3 倍程度という条 件では， $\tau_{a s}$ を考慮した合成粗度係数の予測に際して必 要となる境界混合係数 $f$ の值が, 0.17 程度の値をとる ことが明らかになった．以上により，被を考慮した精 度の高い合成粗度係数予測を行うことが可能となった。

（３）複断面河道の抵抗特性を表わす指標として, 水 深による合成粗度係数の変化と低水路流と高水敷上の流 れとの干渉による合成粗度係数の増加割合を選び, 上記 （1），（2）の成果に基づき，これらの諸量を横断面形 状, 高水敷, 低水路の粗度係数および水深から簡便に求 める方法を示した。

（4）上記の $2 つ の$ 水理量を縦軸と横軸にした複断面 河道抵抗特性分類図を提案し, この分類図上に検討対象 河道の水理量をプロットすることにより，用いるべき合 成粗度係数予測手法の選択や, 改修による水理特性変化 の把握を容易にかつ合理的に行うことができることを示 した.

謝辞：実験と解析を進めるにあたり，長岡技術科 学大学大学院生 渡辺政美君に多大なる援助を受けた. ここに記して感謝の意を表わす.

\section{参 考 文 献}

1) たとえば, Chow, V.T. : Open-Channel Hydraulics, International Student Edition, McGraw-Hill, pp.138 140, 1959.

2）井田至春：広巾員水路の定常流一断面形の影響について 一, 土木学会論文集, 第 69 号別冊 (3-2), 1960.

3）建設省河川局監修：改訂建設省河川砂防技術基準（案） 調查編, 52 年改訂, 山海堂, pp. 185 186, 1977.

4) Zheleznyakov, G. V. : Interaction of Channel and Flood Plain Streams, Proceedings of 14th Congress, IAHR, Paris, France, 1971.

5) Sellin, R.H. J. : A Laboratory Investigation into the Interaction between the Flow in the Channel of a River and that over its Flood Plain, La Houille Blanche, No. 7, pp. 793 801, 1964.

6) Bhowmik, N. G. and Demissie, M. : Carrying Capacity of Flood Plains, Journal of the Hydraulics Division, ASCE, Vol. 108, No. HY3, pp. 443 452, 1982.

7）今本博健 - 久下俊夫 : 複断面流れの水理特性に関する基 礎的研究, 京都大学防災研究所年報, 第 17 号 B, pp. 665 679, 1974.

8）今本博健 - 石垣泰輔 - 稲田修一：複断面開水路流れの水
理特性について, 京都大学防災研究所年報, 第 25 号 B-2, pp. 509 527, 1982.

9）福岡捷二・藤田光一：洪水追跡法 (その 4)-1 次元解析 法の有効性とその適用限界一, 土木技術資料, 第 28 巻, 第 11 号, pp. 46 51, 1986.

10) Toebes, G. H. and Sooky, A. A. : Hydraulics of Meandering Rivers with Flood Plains, Journal of the Waterways and Harbors Division, ASCE, Vol.93, No. WW2, pp. 213 236, 1967.

11) Myers, W. R. C. : Momentum Transfer in a Compound Channel, Journal of Hydraulic Research, Vol. 16, No.2, pp. 139 150, 1978.

12) Wormleaton, P.R., Allen, J. and Hadjipanos, P. : Discharge Assessment in Compound Channel Flow, Journal of the Hydraulics Division, ASCE, Vol.108, No. HY9, pp. 975 994, 1982.

13）石川忠晴 - 山崎真一 - 金丸督司：開水路平面せん断流に 関する実験的研究，第 39 回年次学術講演会概要集，第 2 部, pp. 473〜474, 1984.

14) Ogink, H. J. M. : The Effective Viscosity Coefficient in 2-D Depth-averaged Flow Models, Proceedings of the 21st Congress, IAHR, Melbourne, Australia, 1985.

15) McKee, P. M., Elsawy, E. M. and McKeogh, E. J. : A Study of the Hydraulic Characteristics of Open Channels with Flood-plains, Proceedings of the 21st Congress, IAHR, Melbourne, Australia, 1985.

16）高橋 保：河道における洪水流の特性に関する研究, 京 都大学学位論文, pp. 135 159, 1971.

17) Rajaratnam, N. and Ahmadai, R. : Hydraulics of Channels with Flood-plains, Journal of Hydraulic Research, Vol. 19, No. 1, pp. 43 60, 1981.

18）玉井信行 - 河原能久: 複断面開水路流れの特性と抵抗則 に関する研究, 第 25 回水理講演会論文集, pp. 113 118, 1981.

19) Knight, D. W. and Demetriou, J. D. : Flood Plain and Main Channel Flow Interaction, Journal of Hydraulic Engineering, ASCE, Vol.109, No.8, pp. 1073 1092, 1983.

20) Knight, D. W. and Hamed, M. E. : Boundary Shear in Symmetrical Compound Channels, Journal of Hydraulic Engineering, ASCE, Vol.110, No. 10, pp. 1412 1430, 1984.

21) Nalluri, C. and Judy, N. D. : Interaction between Main Channel and Flood Plain Flow, Proceedings of the 21st Congress, IAHR, Melbourne, Australia, 1985.

22) Noutsopoulos, G. and Hadjipanos, P. : Discharge Computations in Compound Channels, Proceedings of the 20th Congress, IAHR, Moscow, USSR, 1983.

23）福岡捷二ほか：複断面河道における洪水流の抵抗特性, 第 30 回水理講演会論文集, pp. 499 504, 1986.

24）福岡捷二・山坂昌成・清水義彦：平衡形状に着目した中 規模河床形態の卓越波数之形成領域区分, 土木学会論文 集，第 363 号 $/$ II -4, pp. 115 124，1985.

（1988.11.26 - 受付） 